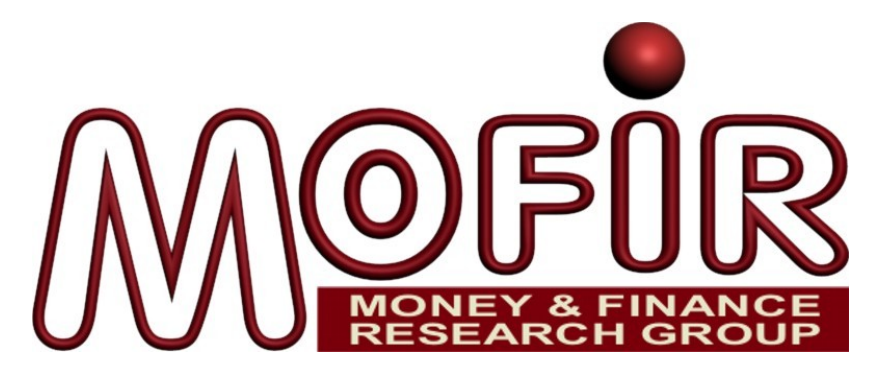

\title{
Geographical Distance and Moral Hazard in MicrocRedit: EvidENCE FROM COLOMBIA
}

\author{
Andrea F. Presbitero \\ Università Politecnica delle Marche \\ MoFiR \\ CeMaFiR \\ RoBerta RABELLOTTI \\ Università Politecnica delle Marche
}

MoFiR working paper $\mathrm{n}^{\circ} 58$

December 2012 


\title{
Geographical Distance and Moral Hazard in Microcredit: Evidence From COLOMBiA*
}

\author{
Andrea F. Presbitero $^{\dagger} \quad$ Roberta Rabellotti ${ }^{\ddagger}$
}

January 28, 2012

\begin{abstract}
Recent years have seen an intense and critical debate about the impact of microcredit on entrepreneurial activities and poor households' welfare. This paper suggests that information asymmetries in the ex-post loan arrangement between the microfinance institution (MFI) and local borrowers could partially explain the limited impact of microcredit. The physical distance separating borrowers from the MFI could be considered a proxy of agency costs, making monitoring more costly and moral hazard easier. The estimation of the effect of distance on the borrower's self-assessed outcome of a microcredit project in Colombia confirms the presence of moral hazard in the microcredit market, with agency costs increasing with geographical distance.
\end{abstract}

JEL Classification: $G 21$, G29, O16

Key words: Microcredit, Colombia, Distance, Relationship Lending.

\footnotetext{
* This paper is the product of a research project conducted in 2005-2006 by the University of Bergamo, the University of Piemonte Orientale and the Giordano Dell'Amore Foundation, with the sponsorship of Fondazione CRT of Turin, coordinated by Roberta Rabellotti and Laura Viganò. The authors warmly thank Alberto Niccoli, Alberto Zazzaro, and participants at the Second European Research Conference on Microfinance (Groningen) for useful suggestions.

${ }^{\dagger}$ Andrea F. Presbitero, Department of Economics - Università Politecnica delle Marche (Italy), Money and Finance Research group (MoFiR) and Centre for Macroeconomic and Finance Research (CeMaFiR). E-mail: a.presbitero@univpm.it; personal webpage: sites.google.com/site/presbitero/.

${ }^{\ddagger}$ Roberta Rabellotti, Department of Political and Social Sciences - Università di Pavia (Italy). E-mail: roberta.rabellotti@unipv.it; personal webpage: sites.google.com/site/robertarabellotti/.
} 


\section{Introduction}

Financial development and improved outreach of the provision of financial services are two key determinants of growth and poverty reduction in developing countries (Burgess and Pande, 2005; Beck, Demirgüç-Kunt and Levine, 2007; Levine, 2008; Demirguc-Kunt, Beck and Honohan, 2008; Arestis and Caner, 2009; Bittencourt, 2010). In many developing economies, financial development has been recently pursued through an intense process of liberalization and globalization of commercial banking services (Hanson, 2003; Cull and Martinez Peria, 2010). Nevertheless, it is a widely held opinion that commercial banks, whether domestic or foreign, are often unable to reach the poor, leaving unbanked a significant share of the population in these countries (Clarke et al., 2005; Beck and Demirgüç-Kunt, 2008; Beck and Martinez Peria, 2010; Stein, 2010). This means depriving the poor of a wide range of opportunities, related, for instance, to their entrepreneurial skills, education access and gender empowerment. Usually, the poor have no access to commercial credit because either they cannot put up acceptable collateral or the screening and monitoring costs for the banks are too high to make lending to them profitable.

Since the late 1970s, microfinance programs have been introduced in many developing economies (Stiglitz, 1998; Hulme and Arun, 2009). Increasingly, microcredit has been enthusiastically considered as an extremely useful instrument to combat poverty, providing access to basic financial services for borrowers traditionally discriminated by formal banking institutions. Economists have theoretically justified the microcredit novel lending mechanism stressing peer monitoring as the key to explain high loan recovery rates (Besley and Coate, 1995; Stiglitz, 1990; Varian, 1990). ${ }^{1}$ Yet empirical research testing these theories has long been largely absent and only recently has there been a surge of new empirical work, mainly using randomized field experiments for testing the impact of a particular microfinance institution or the effect of a specific program. The empirical investigation of the impact of microcredit has originated a passionate, and still open, debate. ${ }^{2}$

The new empirical evidence has often challenged the initial wave of enthusiasm over microcredit, suggesting that "microcredit is not for every household, or even most households [...] and it does not lead to the miraculous social transformation some proponents have claimed. But for some households it has precisely the types of impacts we would expect of a new source of credit" (Banerjee et al., 2010, p. 4). Among the possible explanations of the differentiated impacts of microcredit (Crépon et al., 2011), there are some of the problems traditionally affecting banking activities, such as the costs of monitoring and ex-post moral hazard, which are fueled by asymmetric information between lenders and borrowers.

Traditionally, microcredit has been depicted as a very powerful tool to foster the build-up of trust (Feigenberg, Field and Pande, 2010) and to reduce informational asymmetries between lenders and borrowers, thanks to several devices ranging from group lending and peer-monitoring, to physical proximity and embeddedness in the local community (see the extensive and critical review by Armendáriz and Morduch, 2010). In particular, joint liability group lending should facilitate "screening, monitoring and enforcement of contracts among borrowers, reducing or erasing the agency costs of the lender" (Hermes and Lensink, 2007, p. F2). However, recent evidence points out that the physical distance separating lenders and borrowers might be an important constraint in microcredit markets, increasing transportation and agency costs and restraining the access to finance for borrowers located far away from the microfinance institutions (Pedrosa and Do, 2011).

\footnotetext{
${ }^{1}$ For a review see Ghatak and Guinnane (1999).

${ }^{2}$ See, for instance, the recent book by David Roodman (2012) and Martin Ravallion's analysis of the controversy between Roodman and Murdoch and Pitt and Khandker at: http://blogs.worldbank.org/developmenttalk/the-microfinance-mystery.
} 
The role of geographical distance, defined as the physical distance separating the borrower from the lender, has been widely investigated in recent studies on commercial banking (Alessandrini, Fratianni and Zazzaro, 2009, for a review see) and economic geography (Alessandrini, Presbitero and Zazzaro, 2010), but it has received very limited attention in the microcredit literature. In this paper, we investigate the role of information asymmetries and agency costs in a microcredit program run in Colombia, considering as a proxy of the physical distance between the MFI and the borrower the time necessary for the borrower to reach the MFI branch.

The empirical analysis is based on a survey undertaken in 2005 in Medellin of 100 individuals, weakly connected with the formal banking system, who borrowed from an individual microcredit program managed by Banco de las Oportunidades. In the questionnaire survey, the borrowers were asked to evaluate the benefits obtained from joining the microcredit program under several aspects concerning their households and their businesses, such as family income, housing conditions and total sales. Detailed information on the length of the credit relationship and on the physical distance separating the borrowers from the MFI are also available. Medellin represents an interesting case study because, over the last decade, among Latin American countries Colombia has experienced a quite spectacular increase in the supply of microcredit and Medellin is the first city in which microfinance programs were established, both by international NGOs and by the city government (Bateman, Duran Ortiz and Sinkovic, 2011).

The hypothesis we intend to test is that distance would increase agency costs in microcredit, hindering the success of the loan. Specifically, the greater the physical distance between the MFI and the borrower, the higher should be the cost of monitoring for the lender. Thus, distant borrowers would have a greater incentive to adopt moral hazard and opportunistic behaviors, such as diverting the borrowed money to finance consumption rather than investment or working capital purchases. Since the probability of being detected decreases with distance as monitoring becomes more costly, we should observe a worse outcome of the microcredit, in terms of business activity or investment, the further away the borrower is from the MFI.

This mechanism would be effective if the opportunistic behavior, when sanctioned by the lender, imposed a subsequent cost for the borrower. This is likely to be the case for individuals who are generally unbanked before joining the program, and whose informational opaqueness makes the evaluation of their creditworthiness extremely difficult. These borrowers would have limited outside options in the event of the MFI terminating the credit relationship if it discovered that money had been diverted from the agreed purposes.

Empirically, we test this hypothesis using several different information on the borrowerperceived outcome of the loan in terms of income and housing conditions, business sales and employment. Since all loans were granted for investment or working capital purposes, we consider the discrepancy between the perceived outcome of the loan and its original productive purposes as a measure of the success of the loan. Using a standard probit analysis we assess whether a lower bank-borrower distance, making moral hazard more likely, reduces the perceived effectiveness of the micro-loan.

Unlike the assumption made so far, distance could also be a proxy for different transaction costs other than agency costs. In particular, a long distance could increase transportation costs up to a point of making the visit to the bank a binding constraint for the entrepreneurial activity. To try to disentangle between these two effects - information versus transportation costs - we run an additional exercise in which we allow for a differentiated effect of distance according to the entrepreneur having obtained his/her first loan or being in a longer credit relationship. If distance is a proxy for information asymmetries, it should become uninformative in explaining the success of the loan as long as the duration of the credit relationship increases, since the establishment of a credit relationship reduces information asymmetries (Diamond, 1991; Behr, Entzian and Guttler, 2011), makes monitoring less expensive and reduces the hidden-action 
incentive for the recipient. In particular, the opportunity cost - the future lack of access to microcredit - of diverting money from the original purpose of the loan will increase, given the borrower's limited outside options. By contrast, if distance captures transportation costs, its effect would be the same regardless of whether or not the client is on his/her first loan.

The rest of the paper proceeds as follows. The next section summarizes the literature on the role of distance in banking and microcredit. Section 3 provides some background on the Colombian microcredit sector as well as some detailed information about the survey. Section 4 presents the results of the empirical analysis, aimed at assessing whether the MFI-borrower distance significantly affects the outcome of the loan. Finally, Section 5 concludes, discussing some policy implications to design effective microcredit programs for expanding outreach.

\section{The role of distance in microcredit}

The idea that financial markets do not work in a space-neutral world is by now well established (Klagge and Martin, 2005). In recent years, the literature on banking has seen a growing interest in geographical distance in credit markets, as a proxy for transportation costs and informational asymmetries between lenders and borrowers (Alessandrini, Fratianni and Zazzaro, 2009; Degryse, Kim and Ongena, 2009; Alessandrini, Presbitero and Zazzaro, 2010). The existence of a decentralized banking system is considered to be a key factor for SME access to credit, since local bank branches guarantee personal contacts with borrowers, through which hard and soft information is collected with a reduction in monitoring costs. The advantage of physical proximity is mirrored by the spatial diffusion of bank branches, which reduces the distance between credit institutions and local costumers.

The geographical outreach of microfinance institutions has been less studied, mainly because of the general presumption that MFIs are close to beneficiaries and locally embedded in the communities in which they operate (Bateman and Chang, 2009). Nevertheless, there are studies identifying poor infrastructures, bad geography and low population density as barriers to financial outreach in remote and rural areas (Gulli and Berger, 1999; The Seep Network Poverty Outreach Working Group, 2006). Hence, reaching poor customers in the more marginalized areas of the country generally becomes financially unsustainable.

To the best of our knowledge, the direct effect of the geographical distance separating borrowers and MFIs on access to credit and on loan outcomes has been investigated in very few studies. Two of them look at the repayment rates and find contrasting results: while distance is negatively correlated with the likelihood of microcredit repayments in a survey of 200 rural community MFI members in Nigeria (Oke, Adeyemo and Agbonlahor, 2007), the same effect has not been found in a study of Malaysia using a survey of more than 2,600 customers of the Agrobank Micro Credit Scheme (Roslan and Karim, 2009).

A third study was carried out by Pedrosa and Do (2011), who test on a small sample of borrowers in Niger the predictions of a theoretical model on credit markets. They consider the physical distance between lenders and the MFI as a proxy for transportation costs and informational asymmetries, showing that: 1) the intensity of screening increases with distance, and 2) monitoring is less likely to occur as distance increases. The empirical results are consistent with these hypotheses and point out that the MFI transfers transaction costs onto distant borrowers in terms of higher interest rates, more intensive screening and more restrictive loan conditions.

Building on this literature, in this paper our contribution is to assess the role of physical proximity in reducing informational asymmetries and agency costs, which make the ex-post monitoring of individual micro-loans costly. Rather than looking at the repayment rates, the interest 
rates and the screening activity, we focus exclusively on ex-post moral hazard. ${ }^{3}$ Moreover, differently from Pedrosa and Do (2011), who analyze group liability lending, this paper looks at individual lending. The removal of joint liability brings the monitoring and enforcement of the loan contract back to the lender. Without joint liability, the local MFI cannot take advantage of the group assortative matching and of the peer-monitoring process, which should limit strategic default and ex-post moral hazard (Ghatak, 1999). As a result, in the absence of group lending, as is the case in the microcredit program investigated in this paper, agency costs are more likely to impact on the success of a micro-loan, similarly to the traditional banking services. This hypothesis is consistent with the descriptive evidence provided by Pedrosa and Do (2011), according to whom in order to facilitate monitoring activity, in Niger individual lending is found to be mostly restricted to urban areas, close to microfinance offices.

\section{A descriptive analysis of the microcredit program}

\subsection{Microcredit in Colombia and the Banco de las Oportunidades}

In 2005 when our survey was conducted, the Inter-American Development Bank reports that in Colombia there were 22 MFIs, serving more than 600,000 borrowers (Navajas and Tejerina, 2006), the main operator being the Fundaciùn WWB Calí, with almost 130,000 customers. More recent estimates, undertaken at the end of 2010 by MIX Market, counted a total amount of 34 MFIs in Colombia with about 2.1 million borrowers, the largest institution being the Banco Caja Social Colombia with almost 620,000 active borrowers and a gross loan portfolio of USD 2.4 billion. ${ }^{4}$ According to a study by Vision Economica (Vision Economica, 2011), a local business research group, microcredit in Colombia grew by 15 percent per annum between 2007 and 2010, when the total amount of microloans reached more than USD 4.1 billion. Regulated intermediaries, and in particular Bancos, are responsible for the largest increase, even if NGOs still account for almost half of the microloans totally disbursed.

The microcredit program investigated in this study was established as part of a wider public program called Plan de Desarrollo de Medellin, aimed at promoting the development of Medellin and improving the socio-economic conditions of its citizens. Within this framework, microcredit is conceived as one of the instrument of a wider social and economic assistance program, involving various public and private institutions. Therefore, the project is structured so that the Municipality of Medellin is the main sponsor of the program and involves a local microfinance project - the Banco de las Oportunidades - and a local microfinance institution - the NGO Microempresa de Antioquia - offering both credit and training services. Basically, the Banco's credit activities are actually run by Microempresa de Antioquia, which is mainly funded by international donors. As with several other larger programs and in line with a worldwide trend that acknowledges pitfalls in the group liability lending (Giné and Karlan, 2009), this program is based on individual liability and therefore the cost of monitoring activity remains a prerogative of the lender.

\subsection{Description of the survey}

During the summer of 2005, 100 borrowers of Banco de las Oportunidades were interviewed at their homes or workplace with a closed questionnaire. The interviewees were randomly selected

\footnotetext{
${ }^{3}$ Since all individuals were selected from Banco borrowers, we were unable to investigate the role of geographical distance in the ex-ante screening activity of potential borrowers.

${ }^{4}$ See http://www.mixmarket.org for more detailed data.
} 
from the Banco's dataset of approved credit lines and stratified by income level and economic activity (see Table A.1 in the Appendix). ${ }^{5}$

The questionnaire contains nine sections providing information on some individual characteristics (e.g. age, sex, education) of the program's beneficiaries as well as different aspects of their relationship with the microfinance institution. ${ }^{6}$ Moreover, participants were asked to evaluate the benefits they had obtained from joining the microfinance program with respect to their income, their main business activity, their housing conditions, their assets and land ownership. In every question, the respondents were asked to evaluate the perceived changes (positive, negative, none), after having received the credit.

Of course, asking the respondents about their perception may lead to various limitations, such as misperception of costs and benefits and fear of retaliation, which could bias the beneficiaries' judgment about the program. For this reason, the literature on impact evaluation uses counterfactual analysis and, more recently, randomized control trials (Karlan and Zinman, 2009; Banerjee et al., 2010; Crépon et al., 2011). Nevertheless, due to resource constraints, in this project we did not interview a control group of respondents with the same characteristics as the beneficiaries in the sample. This implies that from a purely quantitative point of view, on the basis of our empirical findings we cannot relate any economic improvement of the respondents to their participation to the program. Despite this limitation, the survey data can still serve the purpose of this paper, which is to appraise the role of distance on the intensity of the borrower-lender informational asymmetries. In other words, even lacking a control group, it is possible to evaluate whether the recipient's perceived positive impact of the loan increases with the repeated interaction between the MFI and the borrower and a shorter distance between the two, which should reduce the costs of monitoring.

\subsection{Descriptive analysis}

\subsubsection{Individual and firm characteristics}

The first part of the questionnaire survey collects some information on the beneficiaries of the microcredit program, presented in Table 1. In the sample, there is a prevalence of women $(56 \%)$ and the mean age is 41 years; males are, on average, almost six years older than females (44 versus 38 years, the difference being statistically significant). The average borrower's household consists of four people, with only 15 borrowers living in households with one or two people. Even if the literacy rate is 92 percent, the level of education is quite heterogeneous: 19 borrowers have no formal education, while 36 completed the primary school and the others reached a secondary or even tertiary level of education.

With regard to economic activities, 78 business-owners were already operating before joining the program, consistent with a general trend found in other microcredit programs in Medellin (Bateman, Duran Ortiz and Sinkovic, 2011). The entrepreneurs have, on average, more than ten years of experience in their sector, in line with the microcredit project guidelines to target entrepreneurs with extensive experience in the sector. With regard to the size of firms, half of the sample is made of individual firms, with just nine businesses having more than two employees. Company activity is concentrated in the retail sector (30 entrepreneurs, mainly men) and in the textiles and clothing industry (21 firms, mainly female-owned).

Table 1 also provides some information on the relationship between the program's beneficiaries and the banking system, showing that only a minority have access to alternative sources of

\footnotetext{
${ }^{5}$ In the Banco's dataset there are 7,279 approved credits, categorized in three main classes of recipients, ranging from the poorest, to intermediate poor and to moderate poor, all of whom are resident in the periphery of Medellin.

${ }^{6}$ For a more detailed description of the survey and the questionnaire see Molini and Rabellotti (2008).
} 
Table 1: Individual and firm characteristics

\begin{tabular}{|c|c|c|c|c|c|}
\hline \multicolumn{6}{|l|}{ Individual characteristics } \\
\hline Age & 100 & 40.87 & 10.80 & 20 & 64 \\
\hline Gender $(1=$ Male; $0=$ Female $)$ & 99 & 0.43 & 0.50 & 0 & 1 \\
\hline Reading $(0=$ No; $1=$ Yes $)$ & 100 & 0.92 & 0.27 & 0 & 1 \\
\hline Years of schooling & 98 & 7.85 & 3.96 & 0 & 16 \\
\hline Household members & 100 & 4.09 & 1.73 & 1 & 11 \\
\hline \multicolumn{6}{|l|}{ Firm characteristics } \\
\hline Former entrepreneur $(0=$ No; $1=$ Yes $)$ & 100 & 0.78 & 0.42 & 0 & 1 \\
\hline Number of employees & 97 & 1.63 & 0.83 & 1 & 6 \\
\hline Years of experience & 95 & 10.50 & 8.31 & 0 & 35 \\
\hline \multicolumn{6}{|c|}{ Relationship with the banking system } \\
\hline Relationship with other banks $(0=$ No; $1=$ Yes $)$ & 99 & 0.36 & 0.48 & 0 & 1 \\
\hline Participation in other microcredit programs $(0=$ No; $1=$ Yes $)$ & 97 & 0.13 & 0.34 & 0 & 1 \\
\hline Application for credit also from other institutions $(0=$ No; $1=$ Yes $)$ & 100 & 0.17 & 0.38 & 0 & 1 \\
\hline Availability of information on other programs $(0=$ No; $1=$ Yes $)$ & 99 & 0.67 & 0.47 & 0 & 1 \\
\hline Not able to borrow from other institutions $(0=$ No; $1=$ Yes $)$ & 100 & 0.33 & 0.47 & 0 & 1 \\
\hline
\end{tabular}

credit. Only 36 borrowers have a relationship with other financial institutions and, of these, 10 individuals use credit instruments and 24 saving instruments.

This suggests that current borrowers have very limited exit options, such that the cost of investment choices, which will limit access to microcredit from borrowers, is particularly high. Indeed, as a provider of microcredit, the Banco's program is not the exclusive solution for all borrowers, but only 13 individuals participate contemporaneously in other (public or private) microcredit programs. Besides, before joining the program, only 17 borrowers applied for credit from other financial institutions: 10 did not receive credit, while five received a loan, albeit under more restrictive (quantity or price) conditions. ${ }^{7}$ By contrast, current borrowers who did not apply for bank credit before joining the program were mainly prevented by high interest rates and lack of requisites, such as collateral.

Therefore our sample appears to be fully representative of this situation, which suggests that the Banco de las Oportunidades microcredit program has effectively targeted the unbanked. This is not surprising in a country like Colombia where the percentage of the adult population with access to a bank account with a financial intermediary in the period under investigation is just $41 \%$ (Demirguc-Kunt, Beck and Honohan, 2008). In the same period, high inflation and economic and political instability have led to an increase in the interest rates, with banks demanding valuable assets as collateral. Therefore, only individuals providing strong guarantees are considered eligible to receive loans, while those with limited assets are generally excluded from the formal credit market. Figure 1 shows the evolution of the ratio between private credit by the financial system over GDP in South-American countries, confirming the relative poor performance of the Colombian banking sector in the first half of the 2000s.

\subsubsection{Credit relationship characteristics}

A specific section of the questionnaire is designed to analyze the characteristics of the credit relationship. Since there is great equality among men and women with regard to the amount,

\footnotetext{
${ }^{7}$ Two individuals did not provide a precise answer about the result of their loan application.
} 
Figure 1: Bank credit to the private sector: Colombia and South-America

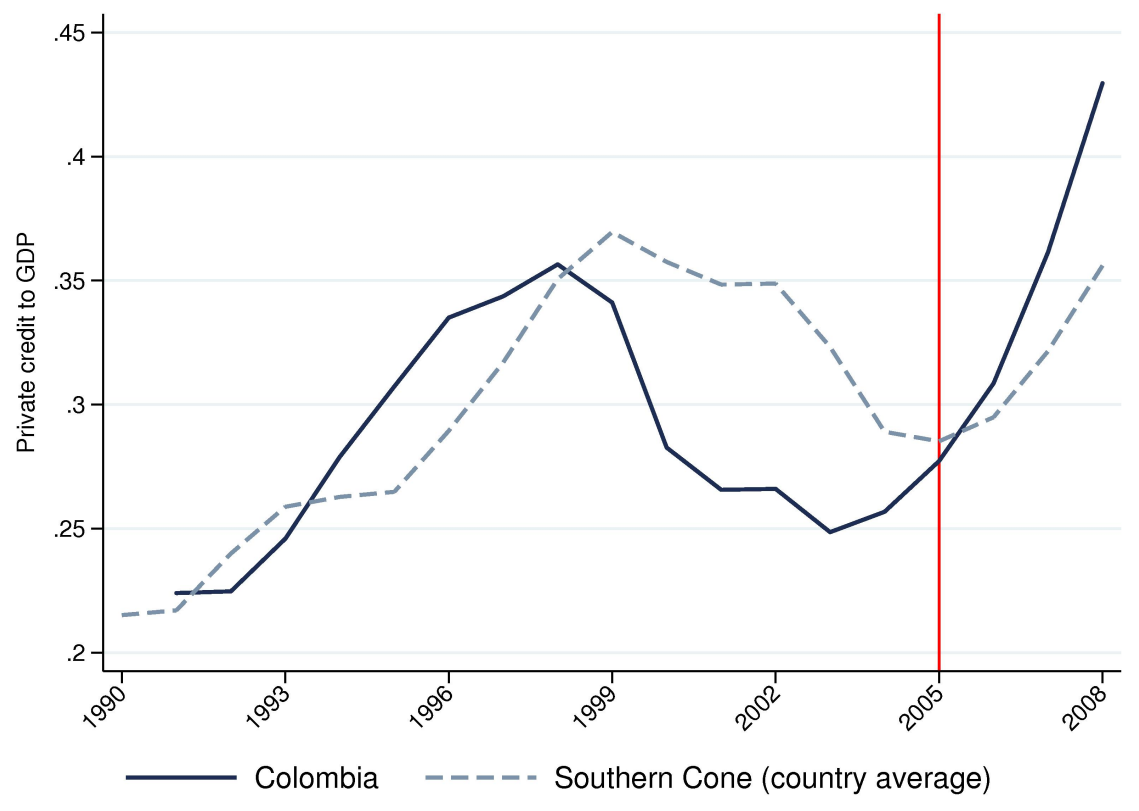

Source: Calculations are based on data about private credit by banks and other financial institutions to GDP in 12 SouthAmerican countries, compiled by (Beck, Demirgüç-Kunt and Levine, 2000; Beck and Demirgüç-Kunt, 2009), over the period 1990-2008.

conditions and length of the loan, Table 2 presents some statistics for the whole sample of respondents. At the time of the interviews, the average borrower had been part of the program for 20 months, with 10 borrowers being enrolled in the program since its inception in 2002 and $30 \%$ of them being very recent customers (less than one year). The length of the loans ranges from 1 to 3 years, with an average of 24 months. Given the short duration of the microcredit program, borrowers have not yet been able to build a long credit history: when interviewed, 42 of them were reimbursing their second loan, while just two were on their third loan. In sum, there are information on 144 loans, 54 of which are already concluded.

Table 2: Credit relationship characteristics

\begin{tabular}{lrrrrr}
\hline & $\begin{array}{c}\text { Obs } \\
\text { Lending relationships }\end{array}$ & Mean & Std. Dev. & Min & Max \\
& & & & & \\
\hline Length (months) & 96 & 19.74 & 10.27 & 0.5 & 36 \\
Distance from the MFI (hours to reach it) & 99 & 0.39 & 0.22 & 0.02 & 1 \\
Number of monthly visits & 100 & 1.03 & 0.17 & 1 & 2 \\
Number of loans & 99 & 1.41 & 0.53 & 1 & 3 \\
& Loan characteristics & & & & \\
\hline Interest rate (\%, monthly) & 144 & 0.91 & 0.00 & 0.91 & 0.91 \\
Length (months) & 144 & 24.39 & 9.66 & 12 & 36 \\
Amount (thousand pesos) & 144 & 2355.14 & 787.66 & 150 & 3800 \\
With problems, i.e. arrears $(0=\mathrm{No}, 1=$ Yes) & 142 & 0.20 & 0.40 & 0 & 1 \\
\hline
\end{tabular}

All borrowers stated that they paid an interest rate of $0.91 \%$ in real terms on a monthly basis, repaying back every month from 4 to $5 \%$ of the principal. Despite the low interest rate, at least 
compared to commercial banks, 27 loans have problems related to reimbursement, mainly due to the accumulation of arrears. Loan size ranges between 150,000 and 3,800,000 pesos, with the average disbursed amount being around 2.3 million pesos, corresponding to about 1,000 USD. Given an average per capita income of 3.17 million pesos in 2005, this means that the average loan, smoothed over a two-year period, corresponds to about $40 \%$ of the annual per capita income. Therefore, the sum disbursed is small and inadequate to accumulate any substantial amount of capital.

Accordingly, the program seems to be more oriented at providing additional resources to acquire working capital, rather than being an instrument to promote investments. Nevertheless, even if loans are very small, $37 \%$ of respondents stated that their primary loan would be used for investing in new tools and small machinery, while $63 \%$ borrowed for working capital needs.

As regards the interaction between the MFI and the borrower, almost all (97\%) borrowers pay a monthly visit to the credit institution. However, there is a great variation in terms of time spent reaching the MFI: for $40 \%$ of the borrowers, the institution is less than 15 minutes away from home, but one third of customers spend more than half an hour reaching the MFI. In general, transportation costs should not matter too much for our sample of borrowers, given the limited time spent monthly reaching the bank. Nevertheless, the spatial diffusion of borrowers with respect to the Banco office could play a significant role in monitoring.

\subsubsection{Microcredit effect}

To assess the way in which customers perceive the economic impact of the program, we consider several alternative indicators. The survey collects and combines various information regarding clients' assessment of the effects of microcredit on their income, on the performance of their business and on their belongings. Four detailed sections of the questionnaire ask direct questions on some measurable indicators to inspect the relationship between the program and some improvements in the well-being of the beneficiaries. In particular, we consider the questions reported in Section IV of the questionnaire about household income, total sales and number of workers in the business activity, and a question in Section VI on housing conditions, which will constitute the dependent variables of the empirical exercise carried out in Section $4 .^{8}$ The housing variables, while not directly related to the original productive purposes of the microloans, might be taken as an indirect proxy of the success of the loan in increasing individual income, given that increased profits from microloans may result in housing upgrades (McIntosh, Villaran and Wydick, 2011). Specifically, the four outcome variables are defined as:

1. a dummy equal to one if the variation in monthly income inside the household since the loan is positive (INCOME);

2. a dummy equal to one for positive changes in total sales since the loan (SALES);

3. a dummy equal to one whether the number of workers has increased since the loan (WORKERS) ${ }^{9}$ and

4. a dummy equal to one if there is a change in housing (i.e. value, availability of services) after the loan (Housing).

\footnotetext{
${ }^{8}$ Given that in informal economies measuring income is very complicated, the validity of the following indicators is checked comparing the income and sales figures with respondents' characteristics and assets in order to verify the consistency of their answers. We expect - and verify - that every interviewee declaring an income increase also registers a positive variation in personal assets, an expansion of his/her business or, finally, the acquisition of new working tools and/or an increase in the working capital/working tools (Molini and Rabellotti, 2008).

${ }^{9}$ For all these three variables, the original question asked for positive, negative or no change; the latter two options were aggregated to create three dichotomous variables.
} 
Table 3: Perceived impact of microcredit

\begin{tabular}{lrrrrr}
\hline & Obs & Mean & Std. Dev. & Min & Max \\
\cline { 2 - 6 } InCOMe $(0,1)$ & 98 & 0.76 & 0.43 & 0 & 1 \\
Sales $(0,1)$ & 99 & 0.74 & 0.44 & 0 & 1 \\
Workers $(0,1)$ & 100 & 0.36 & 0.48 & 0 & 1 \\
Housing $(0,1)$ & 100 & 0.33 & 0.47 & 0 & 1 \\
\hline
\end{tabular}

Notes: All variables are dummies equal to one for positive variations and to zero for negative or no changes in the measured outcome since the start of the loan.

Since microloans have been disbursed in order to finance investments or purchase working capital goods, we can interpret the discrepancy between the original motivation and the actual outcome as a measure of loan success. On the whole, a positive picture emerges from the survey: three out of four borrowers state that their household incomes and/or their business sales increased after the loan. Specifically, the longer the credit relationship, the more likely are improvements in incomes and sales: two thirds of borrowers state that their household income or firm's sales increased in the first year, while this percentage is close to $90 \%$ in the third year of the loan. One third of the recipients were also able to improve their housing conditions and to hire new workers. Even in this case, benefits are more likely to occur in the second and third year of the credit relationship. The lower impact of the program on employment and housing improvements might be due to the stickiness of the decisions to hire new workers and invest in housing improvements. By contrast, the impact on sales and incomes is more likely to be observed immediately after the loan has been obtained.

Given that the sample comprises individual businesses or micro-enterprises, it is not surprising to observe that almost all the individuals whose income increased in the post-loan period, also experienced an acceleration in total sales. Only four people mentioning a higher income lament a negative or no variation in sales.

By contrast, a higher household income is translated into better housing conditions by only $35 \%$ of borrowers ( 7 individuals invested in housing improvements even in the absence of an income increase) and $40 \%$ of those experiencing a boost in sales chose to hire new employees (in four cases, the number of workers increased even without a sale increase).

Since the microloans were granted for purchasing working capital goods and/or undertaking investments in machinery and working tools, these overall positive outcomes are a good result but somehow they are expected. However, it is worth pointing out that a non-negligible share of individuals did not obtain a positive variation in their household income and business activity, even several months after disbursement of the loan. This poor outcome might be due to several reasons, ranging from exogenous negative shocks to opportunistic behaviors. We argue that, if the discrepancy between the loan outcome and the original financing purposes could be taken as a proxy for borrower moral hazard, we would observe a negative correlation between the MFI-borrower physical distance and the likelihood of a positive outcome of the microloan. In the next section we are going to test this hypothesis.

\section{The effect of distance on microcredit}

\subsection{The model}

To estimate the impact of geographical distance on the self-assessed success of the loan, the empirical model is the following: 


$$
\operatorname{Pr}(\text { Outcome })=\Phi(\text { Distance, Relationship Length, Controls })
$$

where Outcome is measured by the four dummies introduced in Section 3.3.3: Income, Sales, Workers and Housing. Distance is the traveling distance (in hours) between the borrower and the MFI. Relationship Length is the duration (in months) of the credit relationship and controls for the possibility that the achievement of the outcome requires time after loan disbursement, as discussed in Section 3.3.3. Moreover, we include a set of control variables such as gender, age, years of schooling, number of household members, number of employees in the firm and two dummies identifying former entrepreneurs and first-time borrowers (from the MFI).

Equation 1 is estimated with a probit model, with robust standard errors (MODEL 1). A negative coefficient on Distance suggests that the physical distance between the MFI and the borrower increases the costs of monitoring and, therefore, makes opportunistic behavior by borrowers - proxied by a poor economic outcome of the micro-loan with respect to its original purposes, - more likely.

To disentangle between an effect of distance due to informational asymmetries and one due to transportation costs, in an augmented specification of Equation 1 (MODEL 2), Distance is inserted separately for first-time borrowers and for recipients at their second or third loan. Assuming that the number of loans is a good proxy of the bank-borrower relationship intensity (Behr, Entzian and Guttler, 2011), if distance is a proxy for informational asymmetries we would expect its impact to vanish as the duration of the credit relationship increases, since monitoring costs and the incentive to opportunistic behavior decrease.

Finally, the robustness of the main findings is tested by changing the set of control variables, including dummies for the sector of activity, for previously rejected borrowers, for individuals with outstanding arrears, and for individuals borrowing from other banks, which should take into account individual riskiness and the possibility of a winner's curse outcome (Shaffer, 1998). ${ }^{10}$

\subsection{Empirical findings}

The results of MODEL 1 are reported in Table 4. Considering first the credit variables, we find that the duration of the credit relationship generally has a positive marginal effect on the loan outcome. This is consistent with the descriptive evidence presented in Section 3.3.3 and with previous evidence (Copestake, Bhalotra and Johnson, 2001; Copestake, 2002), suggesting that the effect of microcredit on actual changes in business profits and household incomes needs time to unfold. Besides, this result could also be explained by a learning-by-doing process. according to which subsequent loans are more effective thanks to a better capacity of banks to fulfill borrowers' needs and to a better investment effort by the recipients.

Taking into account physical proximity, the coefficients of the distance separating the borrower from the MFI is always negative and statistically significant, with the exception of the INCOME model. This result suggests that the transaction costs in monitoring still matter for individual microcredits. The more severe the asymmetric information on the actual use of the money lent, the greater might be the temptation for the recipient to pursue other targets, such as favoring consumption over investment and working capital, hence showing a lower probability of a positive loan outcome.

So far, however, we cannot rule out the possibility that physical distance is a proxy for transportation costs. The results reported in Table 5 support the interpretation of distance as a proxy for informational asymmetries (MODEL 2). In fact, the effect of geographical distance is

\footnotetext{
${ }^{10}$ These results are not shown for reasons of space, but they are available upon request from the authors.
} 
Table 4: Empirical findings: MODEL 1

\begin{tabular}{|c|c|c|c|c|}
\hline Independent variables & $\begin{array}{l}\text { Depender } \\
\text { InCOME }\end{array}$ & $\begin{array}{l}\text { variable: } \\
\text { SALES }\end{array}$ & $\begin{array}{l}\text { Immy for im } \\
\text { WORKERS }\end{array}$ & $\begin{array}{l}\text { vements in: } \\
\text { Housing }\end{array}$ \\
\hline Relationship length & $\begin{array}{c}0.011^{* * *} \\
{[0.004]}\end{array}$ & $\begin{array}{c}0.011^{* *} \\
{[0.005]}\end{array}$ & $\begin{array}{c}0.007 \\
{[0.005]}\end{array}$ & $\begin{array}{c}0.012^{* *} \\
{[0.005]}\end{array}$ \\
\hline Distance & $\begin{array}{l}-0.241 \\
{[0.190]}\end{array}$ & $\begin{array}{c}-0.327^{*} \\
{[0.173]}\end{array}$ & $\begin{array}{r}-0.326^{*} \\
{[0.192]}\end{array}$ & $\begin{array}{c}-0.432^{* *} \\
{[0.213]}\end{array}$ \\
\hline First loan $(0,1)$ & $\begin{array}{c}0.019 \\
{[0.100]}\end{array}$ & $\begin{array}{l}-0.026 \\
{[0.102]}\end{array}$ & $\begin{array}{c}0.003 \\
{[0.105]}\end{array}$ & $\begin{array}{l}-0.087 \\
{[0.104]}\end{array}$ \\
\hline Gender $($ Male $=1)$ & $\begin{array}{c}0.117 \\
{[0.084]}\end{array}$ & $\begin{array}{c}0.075 \\
{[0.081]}\end{array}$ & $\begin{array}{l}-0.042 \\
{[0.096]}\end{array}$ & $\begin{array}{c}0.093 \\
{[0.101]}\end{array}$ \\
\hline Age & $\begin{array}{l}-0.002 \\
{[0.004]}\end{array}$ & $\begin{array}{c}0.001 \\
{[0.004]}\end{array}$ & $\begin{array}{c}0.003 \\
{[0.005]}\end{array}$ & $\begin{array}{l}-0.005 \\
{[0.006]}\end{array}$ \\
\hline Household members & $\begin{array}{c}0.062^{* *} \\
{[0.029]}\end{array}$ & $\begin{array}{l}0.045 \\
{[0.027]}\end{array}$ & $\begin{array}{l}-0.008 \\
{[0.023]}\end{array}$ & $\begin{array}{l}0.057^{* *} \\
{[0.026]}\end{array}$ \\
\hline Years of schooling & $\begin{array}{c}0.030^{* *} \\
{[0.012]}\end{array}$ & $\begin{array}{c}0.030^{* * *} \\
{[0.011]}\end{array}$ & $\begin{array}{c}0.004 \\
{[0.013]}\end{array}$ & $\begin{array}{c}0.019 \\
{[0.014]}\end{array}$ \\
\hline Number of employees & $\begin{array}{c}0.137^{* *} \\
{[0.060]}\end{array}$ & $\begin{array}{l}0.104^{*} \\
{[0.054]}\end{array}$ & $\begin{array}{c}0.118^{* *} \\
{[0.058]}\end{array}$ & $\begin{array}{l}-0.052 \\
{[0.052]}\end{array}$ \\
\hline Former entrepreneur $(0,1)$ & $\begin{array}{c}-0.201^{*} \\
{[0.109]}\end{array}$ & $\begin{array}{c}-0.310^{* *} \\
{[0.133]}\end{array}$ & $\begin{array}{c}-0.393^{* * *} \\
{[0.094]}\end{array}$ & $\begin{array}{c}0.066 \\
{[0.117]}\end{array}$ \\
\hline $\begin{array}{l}\text { Observations } \\
\text { Pseudo } R^{2}\end{array}$ & $\begin{array}{c}87 \\
0.228\end{array}$ & $\begin{array}{c}84 \\
0.198\end{array}$ & $\begin{array}{c}88 \\
0.188\end{array}$ & $\begin{array}{c}88 \\
0.159\end{array}$ \\
\hline
\end{tabular}

Notes: The table reports the average partial effects (APEs) and, in brackets, the associated robust standard errors. * significant at $10 \%{ }^{* *}$ significant at $5 \% ; * * *$ significant at $1 \%$. The model is estimated using the Stata 11 SE package with PROBIT and MARGINS commands.

limited to the first loan and, in that case, it proves significant also for the probability of a positive change in household income. This differentiated effect of distance further confirms the presence of asymmetric information between lenders and borrowers. As long as the latter build their credit history through successive loan applications, the availability of soft information makes monitoring less costly, while the opportunity cost - the future lack of access to microcredit of diverting money from the original purpose of the loan increase, given the borrower's limited alternative options.

The average partial effects of the control variables show that, on the whole, some firm and individual characteristics matter for the outcome of the loan. While age and gender are not significantly associated with a change in income, sales or living conditions, more educated borrowers are more likely to translate the microloan into an actual increase in income and sales. ${ }^{11}$ Customers coming from larger households are more likely to attribute to the loan a positive change in housing and family income, while not in firm-level outcomes, suggesting that family size matters only for personal outcomes. Firm size has a positive effect on the change in the number of workers, in sales and in household income, but not in housing: individuals running larger micro-enterprises seem more able to take advantage of microcredit. Consistent with the mission of the program to provide credit to the unbanked and to support the growth of new businesses, positive variations in household income and firm size (but not in housing) are more likely to happen for new entrepreneurs.

To quantify the economic impact of the credit variables on the perceived success of the loan,

\footnotetext{
${ }^{11}$ The effect of age remains non-significant even when controlling for possible non-linearities, using the logarithm of age, or fitting quadratic specifications.
} 
Table 5: Empirical findings: MODEL 2

\begin{tabular}{lcccc}
\hline \multirow{2}{*}{ Independent variables } & \multicolumn{4}{c}{ Dependent variable: dummy for improvements in: } \\
& INCOME & SALES & WORKER & Housing \\
\hline \multirow{3}{*}{ Relationship length } & $0.011^{* * *}$ & $0.011^{* *}$ & 0.007 & $0.012^{* *}$ \\
& {$[0.004]$} & {$[0.004]$} & {$[0.005]$} & {$[0.005]$} \\
Distance $\times$ First loan $=0$ & 0.024 & -0.025 & 0.014 & -0.441 \\
& {$[0.332]$} & {$[0.317]$} & {$[0.273]$} & {$[0.343]$} \\
Distance $\times$ First loan $=1$ & $-0.441^{*}$ & $-0.561^{* *}$ & $-0.646^{* *}$ & -0.422 \\
& {$[0.225]$} & {$[0.219]$} & {$[0.281]$} & {$[0.276]$} \\
First loan $(0,1)$ & 0.195 & 0.178 & 0.259 & -0.094 \\
& {$[0.176]$} & {$[0.180]$} & {$[0.181]$} & {$[0.197]$} \\
Gender $($ Male $=1)$ & 0.113 & 0.068 & -0.054 & 0.094 \\
Age & {$[0.084]$} & {$[0.080]$} & {$[0.095]$} & {$[0.099]$} \\
Household members & -0.003 & 0.000 & 0.002 & -0.005 \\
& {$[0.004]$} & {$[0.004]$} & {$[0.005]$} & {$[0.006]$} \\
Years of schooling & $0.060^{* *}$ & $0.045^{*}$ & -0.004 & $0.057^{* *}$ \\
& {$[0.027]$} & {$[0.027]$} & {$[0.023]$} & {$[0.026]$} \\
Number of employees & $0.030^{* * *}$ & $0.031^{* * *}$ & 0.007 & 0.019 \\
& {$[0.011]$} & {$[0.011]$} & {$[0.013]$} & {$[0.014]$} \\
Former entrepreneur $(0,1)$ & $0.131^{* *}$ & $0.097^{*}$ & $0.117^{* *}$ & -0.052 \\
& {$[0.058]$} & {$[0.053]$} & {$[0.057]$} & {$[0.052]$} \\
& $-0.190^{*}$ & $-0.289^{* *}$ & $-0.413^{* * *}$ & 0.066 \\
Observations & {$[0.104]$} & {$[0.128]$} & {$[0.089]$} & {$[0.119]$} \\
Pseudo $R^{2}$ & 87 & 84 & 88 & 88 \\
\hline & 0.244 & 0.22 & 0.206 & 0.159 \\
\hline
\end{tabular}

Notes: The table reports the average partial effects (APEs) and, in brackets, the associated robust standard errors. * significant at $10 \%$; ** significant at $5 \%$; *** significant at $1 \%$. The model is estimated using the Stata 11 SE package with PROBIT and MARGINS commands.

the diagrams reported in Figures 2 and 3 show the estimated likelihood of a positive change in business sales and of an improvement in housing conditions according to the length of the MFI-entrepreneur relationship and the physical distance between the two agents. As regards the latter, the estimated probability of a positive variation in sales is higher than 80 percent as long as the MFI is less than 20 minutes away from the borrowers (it is higher than 90 percent for individuals even closer to the MFI), while it decreases to 53 percent for individuals living one hour away from the microfinance office. A similar picture emerges on analyzing the improvement in housing conditions: the probability of a positive change in housing decreases from 40 to 14 percent as the borrower moves from 10 to 45 minutes away from the MFI (Figure 2).

The size of the effect of the duration of the credit relationship is quite similar. Individuals in their first months of relationship with the MFI show a probability of a positive variation in sales of 50 percent, while after one, two and three years this probability increases to, respectively, 70, 85 and 95 percent. A similar picture emerges with regard to housing conditions: the probability of observing an improvement in housing increases from 20 to 35 percent for individuals borrowing for at least one and two years, respectively, from the MFI (Figure 3).

\section{Conclusions}

A growing strand of research in the banking literature stresses the role of distance as a barrier to credit access and as a proxy for informational asymmetries between borrowers and lenders. In the literature on microcredit, great attention has been devoted to bad geography, poor infras- 
Figure 2: Relationship length and the improvements in sales and housing

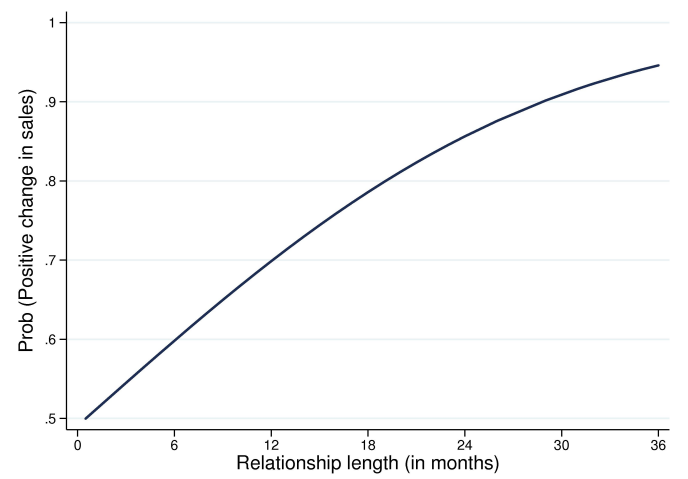

(a) Increase in sales

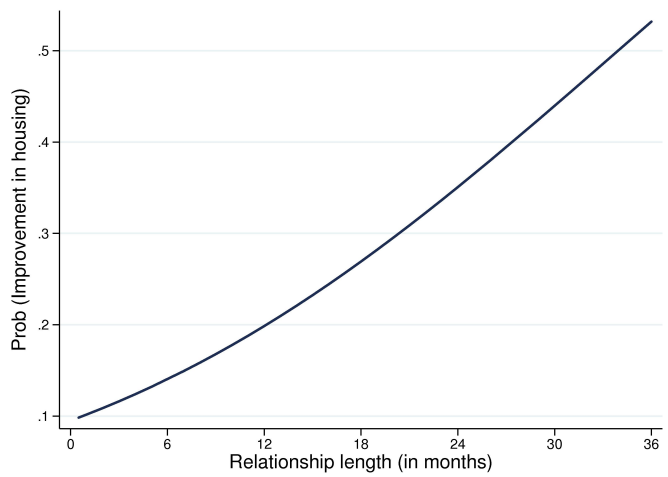

(b) Improvements in housing

Notes: Calculations based on the estimates in Table 4 (columns 2 and 4). All the control variables included in the model are taken at their sample mean.

Figure 3: Distance and the improvements in sales and housing

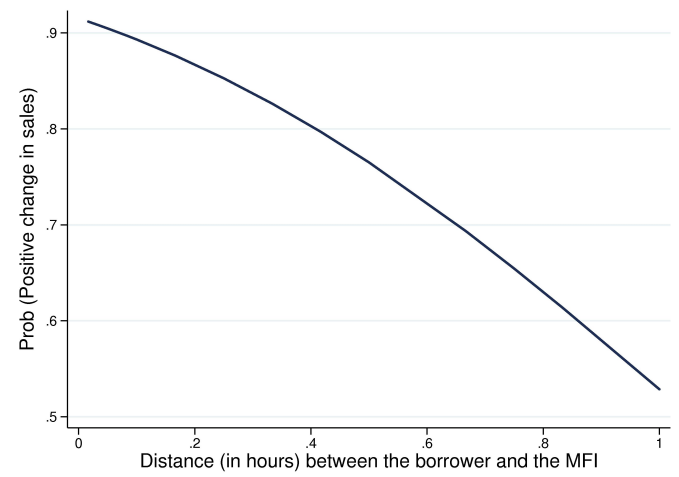

(a) Increase in sales

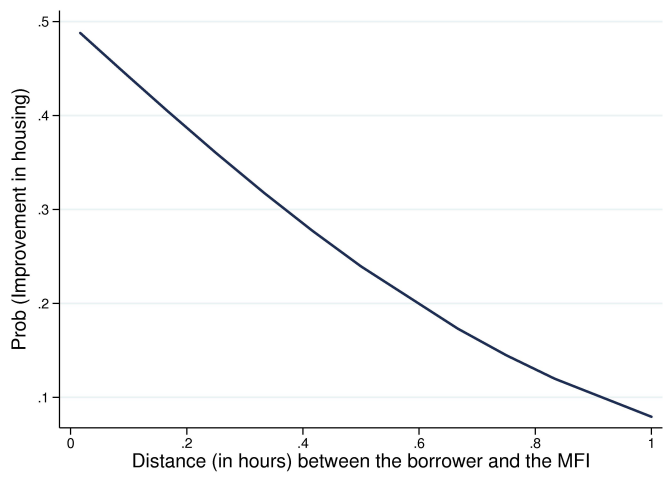

(b) Improvements in housing

Notes: Calculations based on the estimates in Table 4 (columns 2 and 4). All the control variables included in the model are taken at their sample mean.

tructures and low population density, all features increasing transportation costs and limiting bank outreach. Instead, the effect that the bank-borrower geographical distance has on the flow of information during the microloan has hitherto not been carefully investigated.

In this paper we sought to contribute to the literature, using a sample of urban borrowers from a Colombian individual microcredit program to test whether ex-post informational asymmetries, proxied by the bank-borrower distance, matter for microloans to be effective in fostering entrepreneurial activity and living conditions. Our findings show that distant borrowers are less likely to experience an improvement in incomes, business sales and household conditions. Based on this evidence, we can conclude that moral hazard increases with distance, given that monitoring becomes more expensive for the MFI and distant borrowers have greater incentives to adopt opportunistic behaviors. Further confirmation that geographical distance actually measures agency and not transportation costs is drawn from the fact that distance matters exclusively for the first loan. Indeed, in subsequent loans distance is not correlated with the outcome of the loan, consistent with a reduced problem of moral hazard, due to the MFI's better knowledge of 
the recipient and to a limited incentive for the borrower to divert money from working capital expenditure and/or investment in capital goods.

The evidence provided suggests that the spatial diffusion of microfinance institutions is a critical aspect to be considered in the debate on microcredit effectiveness. While reaching the unbanked, still estimated at 2.5 billion people in 2009 (Chala et al., 2009), is a critical policy target to fight poverty and inequality, the instruments for addressing such a goal are yet not well defined. Notwithstanding the caveat related to the absence of a counter-factual and to the data limited to an urban experience in Colombia, two strong implications of our empirical findings are that agency costs are important in individual lending and that geographical distance, increasing monitoring costs, matters for the effectiveness of the loan.

Future strategies to expand outreach of individual microcredit programs should allow for the fact that moral hazard is a critical issue and that physical proximity could contribute to attenuate it. Moreover, further analysis is required for an in-depth understanding of the role of distance in microcredit along several lines. The first is the focus on alternative settings and especially on rural ones, in which low population density and poor transportation infrastructures can make distance an important constraint. A second area of extension is the analysis of the role of distance on interest rates and loan conditions applied by the MFIs.

\section{References}

Alessandrini, Pietro, Andrea F. Presbitero and Alberto Zazzaro. 2010. "Bank Size or Distance: What Hampers Innovation Adoption by SMEs?" Journal of Economic Geography 10(6):845881.

Alessandrini, Pietro, Michele Fratianni and Alberto Zazzaro. 2009. The Changing Geography of Banking and Finance. London: Springer.

Arestis, Philip and Asena Caner. 2009. "Financial liberalization and the geography of poverty." Cambridge Journal of Regions, Economy and Society 2(2):229-244.

Armendáriz, Beatriz and Jonathan Morduch. 2010. The Economics of Microfinance. Second ed. Cambridge: MIT Press.

Banerjee, Abhijit, Esther Duflo, Glennerster Rachel and Cynthia Kinnan. 2010. "The Miracle of Microfinance: Evidence from a Randomized Evaluation." MIT.

Bateman, Milford and Ha-Joon Chang. 2009. The Microfinance Illusion. Technical report University of Cambridge and University of Juraj Dobrila Pula.

Bateman, Milford, Juan Pablo Duran Ortiz and Dean Sinkovic. 2011. Microfinance in Ultrapoor Communities: the Experience of Medellin, Colombia. In Confronting Microfinance Undermining Sustainable Development, ed. Milford Bateman. Herndon, VA: Kumarian Press.

Beck, Thorsten and Asli Demirgüç-Kunt. 2008. "Access to Finance: An Unfinished Agenda." World Bank Economic Review 22(3):383-396.

Beck, Thorsten and Asli Demirgüç-Kunt. 2009. Financial Institutions and Markets Across Countries and over Time: Data and Analysis. World Bank Policy Research Working Paper 4943 The World Bank Washington DC: .

Beck, Thorsten, Asli Demirgüç-Kunt and Ross Levine. 2000. "A New Database on Financial Development and Structure." World Bank Economic Review (14):597-605. 
Beck, Thorsten, Asli Demirgüç-Kunt and Ross Levine. 2007. "Finance, inequality and the poor." Journal of Economic Growth 12(1):27-49.

Beck, Thorsten and Maria Soledad Martinez Peria. 2010. "Foreign bank participation and outreach: Evidence from Mexico." Journal of Financial Intermediation 19(1):52-73.

Behr, Patrick, Annekathrin Entzian and Andre Guttler. 2011. "How Do Lending Relationships Affect Access to Credit and Loan Conditions in Microlending?" Journal of Banking 8$\}$ Finance forthcoming.

Besley, Timothy and Stephen Coate. 1995. "Group lending, repayment incentives and social collateral." Journal of Development Economics 46(1):1-18.

Bittencourt, Manoel. 2010. Financial Development and Economic Growth in Latin America: Schumpeter is Right! Working Papers 201014 University of Pretoria, Department of Economics.

Burgess, Robin and Rohini Pande. 2005. "Do Rural Banks Matter? Evidence from the Indian Social Banking Experiment." American Economic Review 95(3):780-795.

Chala, Alberto, Aparna Dalal, Tony Goland, Maria Jose Gonzalez, Jonathan Morduch and Robert Schiff. 2009. Half the World in Unbanked. Financial access initiative framing note Financial Access Initiative.

Clarke, George, Robert Cull, Maria Soledad Martinez Peria and Susana M Sanchez. 2005. "Bank Lending to Small Businesses in Latin America: Does Bank Origin Matter?" Journal of Money, Credit and Banking 37(1):83-118.

Copestake, J., S. Bhalotra and S. Johnson. 2001. "Assessing the Impact of Microcredit: A Zambian Case Study." The Journal of Development Studies 37(4):81-100.

Copestake, James. 2002. "Inequality and the polarizing impact of microcredit: evidence from Zambia's copperbelt." Journal of International Development 14(6):743-755.

Crépon, Bruno, Florencia Devoto, Esther Duflo and William Parienté. 2011. "Impact of microcredit in rural areas of Morocco: Evidence from a Randomized Evaluation." MIT.

Cull, Robert and Maria Soledad Martinez Peria. 2010. Foreign bank participation in developing countries : what do we know about the drivers and consequences of this phenomenon? Policy Research Working Paper Series 5398 The World Bank.

Degryse, Hans, Moshe Kim and Steven Ongena. 2009. Microeconometrics of banking: methods, applications, and results. Oxford: Oxford University Press.

Demirguc-Kunt, Asli, Thorsten Beck and Patrick Honohan. 2008. Finance for All? Policies and Pitfalls in Expanding Access. Washington DC: The World Bank.

Diamond, Douglas W. 1991. "Monitoring and Reputation: The Choice between Bank Loans and Directly Placed Debt." Journal of Political Economy 99(4):689-721.

Feigenberg, Benjamin, Erica M. Field and Rohini Pande. 2010. Building Social Capital Through MicroFinance. NBER Working Papers 16018 National Bureau of Economic Research, Inc.

Ghatak, Maitreesh. 1999. "Group lending, local information and peer selection." Journal of Development Economics 60(1):27-50. 
Ghatak, Maitreesh and Timothy W. Guinnane. 1999. "The economics of lending with joint liability: theory and practice." Journal of Development Economics 60(1):195-228.

Giné, Xavier and Dean Karlan. 2009. Group versus Individual Liability: Long Term Evidence from Philippine Microcredit Lending Groups. Working Papers 970 Economic Growth Center, Yale University.

Gulli, Hege and Marguerite Berger. 1999. "Microfinance and poverty reduction - Evidence from Latin America." Small Enterprise Development 10(3):16-28.

Hanson, James A. 2003. Banking in developing countries in the 1990s. Policy Research Working Paper Series 3168 The World Bank.

Hermes, Niels and Robert Lensink. 2007. "The empirics of microfinance: what do we know?" Economic Journal 117(517):F1-F10.

Hulme, David and Thankom Arun. 2009. Microfinance - A reader. Routledge Studies in Development Economics London: Routledge.

Karlan, Dean S. and Jonathan Zinman. 2009. Expanding Microenterprise Credit Access: Using Randomized Supply Decisions to Estimate the Impacts in Manila. CEPR Discussion Papers 7396 C.E.P.R.

Klagge, Britta and Ron Martin. 2005. "Decentralized versus centralized financial systems: is there a case for local capital markets?" Journal of Economic Geography 5(4):387-421.

Levine, Ross. 2008. "Finance And The Poor." Manchester School 76(s1):1-13.

McIntosh, Craig, Gonzalo Villaran and Bruce Wydick. 2011. "Microfinance and Home Improvement: Using Retrospective Panel Data to Measure Program Effects on Fundamental Events." World Development 39(6):922-937.

Molini, Vasco and Roberta Rabellotti. 2008. Microfinance and Development: Two Latin American Case Studies. SeMeQ working paper 06/2008 Università del Piemonte Orientale.

Navajas, Sergio and Luis Tejerina. 2006. Microfinance in Latin America and the Caribbean: How Large Is the Market? Sustainable development department best practices series InterAmerican Development Bank Washington DC: .

Oke, J.T.O., R. Adeyemo and M.U. Agbonlahor. 2007. "An Empirical Analysis of Microcredit Repayment in Southwestern Nigeria." Humanities and Social Sciences Journal 2(1):63-74.

Pedrosa, Jose and Quy-Toan Do. 2011. "Geographic Distance and Credit Market Access in Niger." African Development Review 23(3):289-299.

Roodman, David. 2012. Due Diligence. Washington DC: Center for Global Development.

Roslan, Abdul-Hakim and Mohd Zaini Abd Karim. 2009. "Determinants of Microcredit Repayment in Malaysia: The Case of Agrobank." Humanities and Social Sciences Journal 4(1).

Shaffer, Sherrill. 1998. "The Winner's Curse in Banking." Journal of Financial Intermediation $7(4): 359-392$.

Stein, Howard. 2010. "Financial liberalisation, institutional transformation and credit allocation in developing countries: the World Bank and the internationalisation of banking." Cambridge Journal of Economics 34(2):257-273. 
Stiglitz, Joseph E. 1990. "Peer Monitoring and Credit Markets." World Bank Economic Review $4(3): 351-66$.

Stiglitz, Joseph E. 1998. "More Instruments and Broader Goals: Moving Toward the PostWashington Consensus." The 1998 WIDER Annual Lecture (Helsinki, Finland).

The Seep Network Poverty Outreach Working Group. 2006. Microfinance and Non-Financial Services for Very Poor People: Digging Deeper to Find Keys to Success. Poverty outreach working group The SEEP Network.

Varian, Hal R. 1990. "Monitoring Agents with Other Agents." Journal of Institutional and Theoretical Economics 146(1):153-174.

Vision Economica. 2011. "Microcrédito en Colombia." Available online at: http://www.visioneconomica.com/anexo/perfiles2/d1 $\mathrm{a}_{M}$ icrocredito ${ }_{0} 8_{2} 011$.pdf. 


\section{A Additional Tables}

Table A.1: Banco de las Oportunidades approved credits: population and sample

\begin{tabular}{lrcrr}
\hline \multirow{2}{*}{ Sector } & \multicolumn{2}{c}{ Population } & \multicolumn{2}{c}{ Sample } \\
& Loans & Share & Loans & Share \\
\cline { 2 - 5 } & \multicolumn{2}{c}{ Class 1 1: poorest } & & \\
\hline Commercial & 703 & $(60 \%)$ & 11 & $(69 \%)$ \\
Industrial & 306 & $(26 \%)$ & 3 & $(19 \%)$ \\
Services & 123 & $(11 \%)$ & 2 & $(12 \%)$ \\
Rural & 25 & $(2 \%)$ & 0 & $(0 \%)$ \\
Total & 1170 & $(16 \%)$ & 16 & $(16 \%)$
\end{tabular}

Class 2: intermediate poor

\begin{tabular}{lrrrr}
\hline Commercial & 2508 & $(55 \%)$ & 32 & $(51 \%)$ \\
Industrial & 1397 & $(31 \%)$ & 18 & $(29 \%)$ \\
Services & 495 & $(11 \%)$ & 9 & $(14 \%)$ \\
Rural & 107 & $(2 \%)$ & 4 & $(6 \%)$ \\
Total & 4572 & $(63 \%)$ & 63 & $(63 \%)$ \\
\multicolumn{5}{c}{} \\
\multicolumn{5}{c}{ Class 3: moderate poor } \\
Commercial & 788 & $(52 \%)$ & 10 & $(48 \%)$ \\
Industrial & 485 & $(32 \%)$ & 8 & $(38 \%)$ \\
Services & 195 & $(13 \%)$ & 3 & $(14 \%)$ \\
Rural & 12 & $(1 \%)$ & 0 & $(0 \%)$ \\
Total & 1526 & $(21 \%)$ & 21 & $(21 \%)$ \\
\hline
\end{tabular}

Notes: The table reports Banco's dataset of 7,279 approved credits, categorized in three main classes of recipients, ranging from the poorest (Class 1, 16\% of total population), to intermediate poor (Class 2,63\%) and to moderate poor (Class 3, $21 \%$ ), all residing in Medellin's periphery. From these, a sample of 100 loans was randomly drawn, stratifying clients by economic activity and by town districts. 